\title{
Can the Economic Valuation of the Environment be Considered a Problem of Individual Choice?
}

\author{
*Paolo Mossone \\ Fondazione IMC International Marine Centre, Oristano, Italy \\ ${ }^{*}$ Corresponding author: Paolo Mossone, Fondazione IMC International Marine Centre, Oristano, Italy, \\ Email: p.mossone@fondazioneimc.it
}

Received Date: 30 November, 2018; Accepted Date: 24 January, 2019; Published Date: 01 February 2019

The organization of the global economy, and therefore the distribution of wealth and trade-offs between communities and within them, is based on a complex interaction of extraction and up taking of resources, their transformation and the distribution of the resulting product, all mediated by intangible assets called 'services'.

The production processes inherent in this system generate an impact on the environment.

In ecology, the environment is defined as the set of external factors with which an organism interacts. In economics, on the other hand, the concept of the environment assumes an anthropocentric connotation, and is identified as the entirety of the resources that provides vital support to human beings.

The "contamination" between these different points of view is constituted by the ecosystem approach made popular by the Millennium Ecosystem Assessment [1].

The main difficulty in assigning a monetary value to environmental resources lies in their nature as non-market public goods.

We define as public goods the resources whose use by an individual is not incompatible with its use by other (non-rivalrous). Another characteristic of public goods is the non-excludability, that is the impossibility, or at any rate, the difficulty of excluding some individuals from their use [2].

Environmental goods are generally non-market goods since an exchange based on their market value is not possible.

This does not mean that they have no economic value, understood as the measurable quantity of utility related to that good [3], but the crucial problem arises if the benefits from ecosystem services can in fact be privatized even considering their nature as a public good [4].

The efforts of economic theory to find a monetary valuation of the environment [5], therefore, depend on the need to find a unit of measurement that allows for a comparison of the environment's utility [6] with the utility of all other goods and services that people have generated and organized over time for their own livelihood.

In economic terms, the total value of environmental goods and services (TEV) can be broken into different categories of benefits related to their use or existence [7].

$\mathrm{TEV}=$ use value + non-use value

Use value may be direct when it is determined by the productive use of natural resources for human utility (e.g. timber, fishing, tourism), or indirect when it is related to the ecological functions that provide support and protection (e.g. flood and erosion protection, water purification or carbon sequestration).

The value of non-use is based on intangible human benefits, not related to the direct or indirect use of the environmental good:

Intrinsic value: a value recognized as belonging to the environmental good, regardless of any consideration of its productive uses.

- Value of the option and legacy: the value derived from the options relating to the availability of the current and future environmental good, or the value deriving from the conservation of nature for future generations.

- $\quad$ The methods for assessing environmental goods may or may not be based on an approach that involves the construction of a demand curve.

The approaches that do not provide for a demand curve are the following:

\section{Damage function:}

Dose response methods: based on the cost of physiolog- 
ical reactions of humans, plants and animals to pollution (pollution stress);

Replacement or restoration costs: this approach takes into account the cost of replacing or restoring a damaged property and use this value as a measure of the benefit of this restoration;

- $\quad$ Reduction behavior: this approach takes into account the cost involved in the prevention of environmental damage and uses this value as a measure of the benefits of avoiding such damage.

\section{Opportunity cost [8] (indirect value):}

- $\quad$ The benefits of the activity that causes environmental degradation are estimated in order to measure the increase in environmental benefits which would be necessary to discourage the impacting investment.

The methods based on the construction of a demand curve can be direct or indirect:

- $\quad$ Direct methods (stated preferences) simulate the existence of a market for environmental goods or services. The most common methods concern hedonic prices and travel costs and are based on the valuation of the value of use "ex-post". This is calculated based on the preferences expressed by the consumer through different methods, in order to evaluate the economic effort aimed at the enjoyment of the environmental good.

- Indirect methods (revealed preferences) attribute a monetary value indirectly, through the analysis of changes in the consumption of market goods which are related to the environmental good or service. The most common method is the contingent valuation, based on the construction of a demand curve starting from a survey to determine the willingness to pay (WTP) for an environmental good or service through the compilation of questionnaires, or a referendum or an auction.

The biggest problem of this whole approach of evaluating ecosystems economically by attributing a market value to the services they provide, consists in the prevalence of what humans perceive as useful for their own purposes. Once again, we are faced with an anthropocentric vision.

Dealing with the concept of 'value' means tackling a complex and subjective topic that involves the system of individual preferences that forms the exchange ratios: what to sacrifice to get what benefit? For this reason, the evaluation of the ecosystems and the associated benefits is a process far from unequivocal [9].

For an ecologist to attribute value to an ecosystem, it means evaluating factors such as integrity, health or resilience, with the help of measurable indicators.

The European Union seems to refer to this ecological approach, in the part of the 'Habitats' Directive in which it makes the implementation of infrastructural investments within the sites of community importance subject to the assessment of 'favorable conservation status'.

It is difficult to find a meeting point between an ecological approach and an economic approach based on the individual evaluation of the utility (or the sacrificability) of an ecosystem service, although the economists have for this purpose elaborated the concept of 'intrinsic value'. The independence of the intrinsic value with respect to the use value has not been demonstrated by the various valuation methods [10].

It is often stated that direct methods, as well as methods without a demand curve, only allow for the reconstruction of the value of direct use related to a specific ecosystem service, while indirect methods can capture the entire TEV [11]. In reality, there is no objective evidence that the valuation of WTP for an environmental good is not influenced mainly by the utility attributed to it by those who express their preference through a hypothetical market price.

Economic theory, particularly in the neoclassical approach, postulates the rationality of individual choice aimed at maximizing total utility. There is no lack of criticism of this approach [12], but in general this simplification is accepted as a necessary basis for the subsequent elaboration of the model of decision-making [13].

Is it possible to continue using means that focus on determining what is valuable to the individual in order to attribute a value of non-use of a public good?

For example, how many people would be willing to attribute a positive monetary value to a habitat, situated near a tourist settlement that hosted a bacterial community of great ecological importance but emanated an unpleasant smell? What valuation would the individual give when interviewed in the formulation of the WTP?

We see examples of this kind every day. On Mediterranean beaches, deposits ("banquettes") of dead Posidonia oceanica leaves accumulate. These "banquettes" emit a smell of decomposition and compromise the image of the sandy, white beaches normally used in the advertising of these tourist places. However, at the same time, they play very important ecological roles, thus providing valuable ecosystem services, such as protecting the beaches from erosion [14].

In a recent survey in five Mediterranean countries among beachgoers, tourists and locals [15], it emerged that the presence of such banquettes is poorly evaluated. Despite the widespread awareness of their important role in beach equilibrium, the marginal WTP for the maintenance of such beaches in their natural state is very low or even zero. Meanwhile, the valuation by the point of view of travel costs and hedonic prices produces an even negative value due to the fact that beachgoers avoid going to the beaches where there are banquettes.

In the specific case obtained from a sample of 1200 beachgoers, 
the WTP for the maintenance of the natural beach (i.e. with natural deposits of Posidonia oceanica) resulting from the survey amounted to US $\$ 2.36 / \mathrm{m}^{2}$, while the cost resulting from the loss of tourists caused by the presence of the banquette amounts to US $\$ 3.35 / \mathrm{m}^{2}$.

The obtained WTP should represent the TEV including the intrinsic (non-use) value of the natural beach attributed by the respondents, although informed of the function of the banquette as protection against beach erosion.

The loss of an ecosystem service provided by the banquette, neglected by the interviewees as in the example above, can cause, as an alternative to the loss of the beach due to erosion, financial losses for nourishment in the order of about US \$ 100 / year / $\mathrm{m}^{2}[16]$.

In the considered example, the recreational services provided by the beach clearly have a preponderant weight in the individual evaluation of the interviewees. This situation has been perfectly understood by the local administrators of the considered coastal areas, which in fact predominantly $(54 \%)$ declare to base their decisions regarding the management of the beach on the needs of tourists.

From the above example, it emerges that the theoretical evaluation of economists, applied to a practical case, is based on the individual choices of the stakeholders as well as the behavior of the local administrators. In doing so neither the economists nor the local administrators take into account the marginal value of the environmental good, in cases where it is on an ecological threshold and its alteration can produce a sudden collapse of the ecosystem services offered [6].

These considerations seem to suggest, albeit indirectly, that even the methods of economic valuation of the environmental goods based on revealed preferences, tend to be influenced dramatically by the use value without any evidence that the intrinsic value is being taken into account.

This happens especially in cases where the interviewee (e.g. a tourist) has already stated his preferences through payment for a specific ecosystem service provided by these assets, despite the questionnaires used for the contingent evaluation have been specifically designed to investigate non-use values [17].

The development of these considerations indirectly confirms a common criticism of the method of the contingent valuation, based on the fact that the WTP appears to be detached from the theory of rational choices. This is not only related to the argument that the WTP is independent of the quantity available of the good to be protected [18], but also to the fact that we are faced with a typical case of market failure, in which the pursuit of the maximization of utility by individuals is in contrast with the objectives of collective well-being [19] inherent in the notion of public good.

\section{References}

1. Millennium Ecosystem Assessment, Ecosystems and Human Well-being: Synthesis., Washington, DC: Island Press, 2005.

2. I Kaul, I Grunberg, M A Stern (1999) Global public goods - International cooperation in the 21st century, New York, Oxford: Oxford University Press.

3. C Sellar, J Chavas, J Stoll (1986) Specification of the Logit Model: The Case of Valuation of Nonmarket Goods. J Environ Econ Manage 13: 382-390.

4. G Chichilnisky, G Heal (1998) Economic returns from the biosphere. Nature 391: 629-630.

5. E Gomez Baggethun, R de Groot, P L Lomas, C Montes (2010) The history of ecosystem services in economic theory and prctice: From early notions to market and payments schemes. Ecolog Economics 69:1209-1218.

6. S C Farber, R Costanza, M A Wilson (2002) Economic and ecological concepts for valuing ecosystem services. Ecological Economics 41: $375-392$.

7. D Pearce (1993) Economic values and the natural world, London. Earthscan Publications Limited 303-328.

8. A Ruijs, M Kortelainen, A Wossink, C Schulp, R Alkemade (2017) Opportunity cost estimation of ecosystem services. Environ Resource Economics 66: 717-747.

9. M Small, M Munday, I Durance (2017) Tha challenge of valuing ecosystem services that have no material benefits. Global Environmental Change 44: 57-67.

10. M D Davidson (2013) On relation between ecosystem services, intrinsec value, existence value and economic valuation. Ecological Economics 95: 171-177.

11. R Carson, F N E,M N F (2001) Contingent Valuation: Controversies and Evidence. Environmental and Resource Economics 19: 173-210.

12. J M Gowdy, K Mayumi (2001) Reformulating the foundations of consumer choice theory and environmental valuation. Ecological Economics 39: 223-237.

13. P Krugman (1998) Rationales for rationality. in Rationality in Economics: Alternative Perspectives, Dordrecht, Kluwer Academic Publishers 111-122.

14. S Simeone, G De Falco (2013) Posidonia oceanica banquette removal: sedimentological, geomorphological and ecological implications. J Coastal Research 65: 1045-1050.

15. P Mossone, I Guala, H Heurtefeux, M Giunta Fornasin, Y Issaris et al. (2018) Posidonia beach/dunes socio-economic evaluation. POSBEMED Final Report. Oristano: Fondazione IMC - International Marine Centre. ISBN 9788885983106.

16. J J Muñoz, B Lopez, J M Gutierrez, L Moreno, G J Cuen et al. (2001) Comments on Confirmation of beach accretion by grain-size trend analysis: Camposoto beach, Cádiz, SW Spain. Coastal Engeneering by (2013) Geo-Marine Letters 42: 143-153.

17. W G Hutchinson, S M Chilton, J Davis (1995) Measuring non-use value of environmental goods using the contingent valuation method: problems of information and cognition and the application of cognitive questionnaire design methods. J Agri Economics 46: 97-112. 
18. K Arrow, R Solow, P R Portney, E E Leamer, R Radner et al. (1993) Report of the NOAA Panel on Contingent Valuation. National Oceanic and Atmospheric Administration.
19. R Costanza (2000) Social Goals and the Valuation of Ecosystem Services. Ecosystems 3: 4-10.

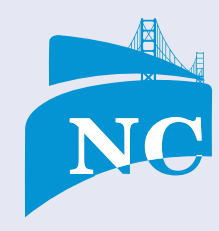

OPONACCES R

submit your manuscripts at

www. norcaloa.com 